\title{
PROTECTION OF PEACEKEEPING FORCES BASED ON THE CONVENTION ON THE SAFETY
}

\author{
Fitri Rohmadhanita \\ Kantor Advokat dan Konsultan Hukum Abi Hasan Mu'an \& Rekan, Indonesia, \\ E-mail: fitrirohmadhanita@gmail.com
}

Submitted: August 18, 2020; Reviewed: February 22, 2021; Accepted: March 2, 2021

\begin{tabular}{ll}
\hline \multicolumn{1}{c}{ Article Info } & \multicolumn{1}{c}{ Abstract } \\
\hline Keywords: & The attacks and threats directed at UN personnel and related \\
UN Personnel, Associated & $\begin{array}{l}\text { personnel resulted in injuries and death. Therefore, to protect } \\
\text { these personnel, the GA established a Resolution, namely the }\end{array}$ \\
Personnel, Protection, & Convention on Safety, which aims to protect UN personnel \\
Attack, and Jurisdiction. & while carrying out its mission. The 1994 Convention on the \\
DOI: & $\begin{array}{l}\text { Safety of the United Nations and Associated Personnel } \\
\text { regulates protected personnel and regulates prohibited acts to }\end{array}$ \\
10.25041/lajil.v3i1.2104 & extradite perpetrators. The Convention urges the host country \\
& (Host Country) to determine its jurisdiction in extraditing \\
& perpetrators of crimes against personnel UN and related \\
& personnel without delay. Given that each country has \\
& sovereignty in its territory and is entitled to determine a \\
national legal system that determines national law application \\
based on jurisdiction.
\end{tabular}

\section{A. Introduction}

The international problems of the global system are about territorial and political security. ${ }^{1}$ There are various problems in International Relations, ranging from the economy, transnational crimes to crimes against humanity, and conflicts within countries, and international conflicts. ${ }^{2}$ The problems that occur often lead to various losses; therefore, there are efforts to prevent and end these problems, namely through peacekeeping operations under the United Nations authority. ${ }^{3}$ The United Nations Peacekeeping Operation is one of the mechanisms for maintaining international peace embodied in the observer mission and the United Nations Peacekeeping Force. ${ }^{4}$ Also, Peacekeeping is a technique by the United Nations to help control

\footnotetext{
${ }^{1}$ Fulvio Attina, "INTERNATIONAL RELATIONS AND CONTEMPORARY WORLD ISSUES", International Relations Encyclopedia of Life Support Systems (EOLSS) 2, (2005): 148-174, 152, DOI: 10.4324/978020398413012.

2 Mohamad Rosyidin, "KONFLIK INTERNASIONAL ABAD KE-21? BENTURAN ANTAR NEGARA DEMOKRASI DAN MASA DEPAN POLITIK DUNIA", Jurnal Ilmu Sosial dan Ilmu Politik 18, no. 3 (2015): 223-236, 223, DOI: 10.22146/jsp.13137

${ }^{3}$ Adji Samekto, "MENGKAJI PERAN OPERASI PEMELIHRAAN PERDAMAIAN PBB SEBAGAI BAGIAN UPAYA MENCIPTAKAN PERDAMAIAN DUNIA", Jurnal Hukum dan Pembangunan 21, no. 1 (1991): 25-35, 25, DOI: 10.21143/jhp.vol21.no1.395.

${ }^{4}$ Athambawa Sarjoon, Mohammed Agus Yusoff, "THE UNITED NATIONS PEACEKEEPING OPERATIONS AND CHALLENGES”, Academic Journal of Interdisciplinary Studies 8, no. 3 (2019): 202-211, 202, DOI: 10.2478/ajis-2019-0059.
} 
and resolve armed conflicts. Both are intended to prevent a situation from worsening to problems in international relations. ${ }^{5}$

As mandated by the UN Security Council, peacekeeping operations are established of international sanctions and the authorization of military action through Security Council resolutions. ${ }^{6}$ The UN peacekeeping has successful in some cases like Sierra Leone and Mozambique, and El Salvador, but they have failures in Somalia, Rwanda, and BosniaHerzegovina. ${ }^{7}$ Several elements must be taken concerning the conduct of UN peacekeeping forces. $^{8}$

United Nations is responsible for keeping security regulated in the UN Charter; the Security Council takes responsibility. ${ }^{9}$ Chapter VI UN Charter regulated collective security, which covered the voluntary settlement of disputes, and Chapter VII regulated enforcement action. ${ }^{10}$ However, they are both peacekeepers that involve armed forces and have the authority to take actions that may be required under Chapter VII of the United Nations Charter and aim to reduce and resolve conflicts. ${ }^{11}$ But now, UN operations are not only used for conflict problems but are also used to carry out administrative functions or tasks, checking the truth of a peace agreement both internal and international to training, monitoring the movement of troop withdrawals, and mine clearance operations. ${ }^{12}$

Like the mission formed by the United Nations in April 1989 to March 1990, namely UNTAG, this mission is tasked with carrying out missions in the post-conflict period, namely monitoring the peace process and general elections in Namibia, South Africa, under the supervision and UN control. Through the UN's transitional assistance group. ${ }^{13}$ Peacekeepers also often volunteer to help with natural disasters in a country, for example, peacekeepers in Haiti, namely MINUSTAH. MINUSTAH troops are helping Haiti to rehabilitate and reconstruct the area after the earthquake. An earthquake measuring seven on the Richter scale in January 2010 killed around 316 people, injured 300 people and made a million people homeless. ${ }^{14}$

The UN missions above are often faced with dangers such as accidents, violence, and assaults to killings aimed at UN personnel and associated UN personnel. These attacks are

\footnotetext{
${ }^{5}$ Marrack Goulding, "THE EVOLUTION OF UNITED NATIONS PEACEKEEPING”, International Affairs 69, no. 3 (1993): 451-464, 452, DOI: 10.2307/2622309.

${ }^{6}$ Siphesihle E.Mpanza, Victor H. Mlambo, "UN PEACEKEEPING MISSIONS IN AFRICA, A CONUNDRUM OR OPPORTUNITY: A CASE OF THE DEMOCRATIC REPUBLIC OF CONGO, SOUTH SUDAN AND THE CENTRAL AFRICAN REPUBLIC", African Renaissance 16, no. 4 (2019): 9-32, 10, DOI: 10.31920/25165305/2019/16n1a1.

${ }^{7}$ Ogunrotifa Ayodeji Bayo, "THE FACTORS BEHIND SUCCESSES AND FAILURES OF UNITED NATIONS PEACEKEEPING MISSIONS: A CASE OF THE DEMOCRATIC REPUBLIC OF CONGO”, Journal of Alternative Perspectives in the Social Sciences 3, no. 4 (2012): 914-932, 915.

8 Paolo Palchetti, "INTERNATIONAL RESPONSIBILITY FOR CONDUCT OF UNPEACEKEEPING FORCES: THE QUESTION OF ATTRIBUTION", Sequência (Florianópolis) 70, (2015): 19-56, 26, DOI: 10.5007/2177-7055.2015v36n70p19.

9 Jane E. Stromseth, "AN IMPERIAL SECURITY COUNCIL? IMPLEMENTING SECURITY COUNCIL RESOLUTIONS 1373 AND 1390", Georgetown Law Faculty Publications and Other Works 97, (2003): 41-54, 42.

${ }^{10}$ Frederick M. Burkle, "COMMENTARY UNITED NATIONS CHARTER, CHAPTER VII, ARTICLE 43: NOW OR NEVER”, Disaster Medicine and Public Health Preparedness 13, no. 4 (2017): 655-66, 665, DOI: 10.1017/dmp.2018.43.

${ }^{11}$ Wolfgang Weiß, "SECURITY COUNCIL POWERS AND THE EXIGENCIES OF JUSTICE AFTER WAR", Max Planck Yearbook of United Nations Law 12, no. 1 (2008): 1-38, 1, DOI: 10.1163/18757413-90000020a.

${ }^{12}$ Malcolm N. Shaw QC, Hukum Internasional, Nusa Media, Bandung, 2013, pg. 1241.

13 Security Council Resolution 626 of 1989, UNTAG monitors South African troops' withdrawal and detains SWAPO forces at the Angola and Zaire Headquarters, and assists the general election process. See also Security Council Resolution 894 of 1994. More than 1,800 election observers were sent.

${ }^{14} \mathrm{https}: / /$ republika.co.id/berita/lja8rx/tni-bakal-terjunkan-tim-pertama-ke-haiti accessed on June 12, 2020.
} 
sometimes carried out by several rebel groups who are not responsible because to protect personnel; the GA (General Assembly) formed a Resolution for the protection of UN personnel sent to carry out UN missions in a country, with the name Convention on the safety, established on December 9, 1994, in Resolution 49/59 of the GA. ${ }^{15}$ This Convention aims to regulate and protect UN Personnel and Associated United Nations Personnel to carry out their mission correctly; this force must be protected from any violence or attacks intentionally directed at it. Given that UN Personnel and Associated UN Personnel's Safety is carrying out their duties, there are considerable risks.

\section{B. Discussion and Analysis}

Discussion and analysis will further explain and describe 2 (two) main issues, protection of UN personnel in the Convention on the safety and enforcement of jurisdiction against perpetrators of attack personnel.

\section{Protection of $\mathbf{U N}$ personnel in the Convention on the safety}

UN personnel are assigned with the primary objective of maintaining international peace and security; this personnel is entitled to receive protection and receive their rights as protected subjects. Before the creation of this Convention, $202 \mathrm{UN}$ personnel died in UN operations. ${ }^{16}$ So that on December 9, 1994, an international convention was formed, namely the Convention on the Safety of the United Nations and Associated Personnel; this Convention is a legal affair governing the protection of the safety of personnel. UN GA adopted this Convention in Resolution 49/59; Creating this Convention is based on concerns over the safety of personnel involved in UN operations in various countries. This Convention consists of 29 Articles. The provisions of the articles in this Convention are based on the United Nations' need to protect the personnel involved in its operations. The first part of the Convention on the Safety of UN personnel defines or details who and what is meant by personnel.

\section{a. Scope of Personnel}

This Convention divides personnel into two parts in support of UN Missions, namely UN personnel, which includes people who are involved or deployed by the SG (SG) as members of the military, police, or civilian components involved in UN operations and whose UN personnel also include officials and experts of UN missions. Or specialized agencies or the IAEA present at UN missions. Whereas the second is Associated Personnel, this personnel are people assigned by the government or by an intergovernmental or non-governmental organization based on an agreement with the SG to carry out activities to support the UN operational fulfillment mandate. Associated personnel themselves are divided into three different groups, namely:

1) Refers to a person assigned by a government or an intergovernmental organization with UN approval, such as NATO.

2) Associated personnel or people involved by the UN SG, UN personnel, and other parties' needs. For example, the involvement of UNICEF and UNHCR in various UN peacekeeping missions, one of which is the United Nations Support Mission in Libya (UNSMIL).

3) Associated personnel is included in non-governmental organization (NGO) bodies involved in UN missions by the mandate or agreement between NGOs and the UN. ${ }^{17}$

\footnotetext{
${ }^{15}$ Resolution Adopted by the General Assembly Forty-ninth session Agenda item 37 (c), A/RES/49/December 22 13, 1994, Available online https://documents-ddsny.un.org/doc/UNDOC/GEN/N94/601/17/PDF/N9460117.pdf?OpenElement

${ }^{16}$ UNDoc.A/AC242/1,paraf 6, (1994).

${ }^{17}$ Article 1 point (a) \& (b) Convention on the Safety of United Nations And Associated Personnel, "United Nations personnel", means "Persons engaged or deployed by the SG of the UN as members of the military, police, or civilian components of a United Nations operation...." and "Associated personnel" means "Persons assigned by a
} 
UN personnel and personnel involved in carrying out its operational missions have the right and authority to be protected from all harm; state parties must protect personnel as operating missions are often faced with "extraordinary risks to personnel safety".

\section{b. Scope of Operation}

Article 2 (1) states that this Convention applies concerning the UN and associated personnel and operations of the UN, as defined in Article 1, namely operations established by a competent UN agency by the UN Charter and carried out under UN authority and control. These operations shall fall into one of two categories covered by this Convention; the first includes operations to maintain or restoring international peace and security. The second includes operations in which the Security Council or GA has declared, for the Convention, that there is the exclusion of extraordinary risks to personnel's safety in participating in operations. ${ }^{18}$

However, Article 2 (2) explicitly establishes a limitation, namely that this Convention does not apply to operations ratified by the UN Security Council based on Chapter VII of the UN Charter. In contrast, Article 1 defines UN Operations referred to as operations established by the United Nations by the UN Charter. They are done under UN authority and state control. In particular, the Convention on UN personnel's safety excludes protection for personnel who participate in official operations under the authority and control of the UN Security Council in Chapter VII. However, several UN Security Council missions are not based on Chapter VII, along with a list of these missions. ${ }^{19}$

Table 1.1

List of UN Missions Not Based on Chapter VII

\begin{tabular}{|l|c|}
\hline \multicolumn{1}{|c|}{ Misi } & Lokasi \\
\hline United Nations Observer & Georgia \\
Mission in Georgia (UNOMIG) & \\
\hline $\begin{array}{l}\text { United Nations Assistance } \\
\text { Mission for Rwanda (UNAMIR) }\end{array}$ & Rwanda \\
\hline $\begin{array}{l}\text { United Nations Truce } \\
\text { Supervision Israel } \\
\text { Organization (UNTSO) }\end{array}$ \\
\hline $\begin{array}{l}\text { United Nations Interim Force in } \\
\text { Lebanon (UNIFIL) }\end{array}$ \\
\hline
\end{tabular}

Specificity in the scope of UN operations regulated in this Convention, making the United Nations form an optional protocol in 2005 to expand the scope associated with the protection law for UN Personnel and Associated UN Personnel regulated in the Convention on the safety. ${ }^{20}$

Government or an intergovernmental organization with the agreement of the competent organ of the United Nations; Persons engaged by the Secretary-General of the United Nations or by a specialized agency or by the International Atomic Energy Agency..."

18 Article 1 point (c) Convention on the Safety of United Nations And Associated Personnel "United Nations operation" means an operation established by the competent organ of the United Nations by the Charter of the United Nations and conducted under United Nations authority and control: Where the operation is to maintain or restore international peace and security; or..."

19 Timo Smit \& Jair van der Lijn, Peacekeepers Under Threat? Fatality Trends In UN Peace Operations (Stockholm: Stockholm International Peace Research Institute, 2015), 7.

${ }^{20}$ Convention on the Safety of United Nations and Associated Personnel, December 9, 1994, 2051 UNTS 361 (78 parties 2005-0 )-0) according to the UN Treaty Section http://untreaty.un.org/English/treaty.asp). The scope of application of the Convention, see Report of the Ad Hoc Committee on the Scope of Legal Protection under the Convention on the Safety of United Nations and Associated Personnel, UN GAOR 57th Sess., Supp. No. 52, UN Doc. A/57/52 (2002), Report of the Ad Hoc, UN GAOR 58th Sess., Supp. No. 52, UN Doc. A/58/52 (2003), and Report of the Ad Hoc Committee, UN GAOR 59th Sess., Supp. No. 52, UN Doc. A/59/52 (2004). 
This additional protocol is the application of the Scope of this Convention applies concerning all other UN operations established by the competent organs of the United Nations by the Charter of the United Nations and carried out under the authority of the United Nations to provide humanitarian, political, or peacebuilding assistance to the provision of other emergency assistance so that the personnel involved in the above missions need to be protected from all dangers, especially those provided for in Article 9 of this Convention. ${ }^{21}$

\section{c. Scope of Protection}

UN Personnel and Related UN Personnel, who are in the host country or the location where the operational mission is being carried out, are entitled to receive protection and receive their rights as stipulated in Article $7 .{ }^{22}$ Based on the explanation of the contents of Article 7 above, it has been explained that UN personnel and associated personnel, their equipment, and buildings must not be the object of an attack or any action that prevents them from releasing their mandate that is being carried out. This article also explains that state parties must take all appropriate steps to ensure personnel safety and security. The countries were taken by the countries concerned in protecting these personnel in their territory as provided in Article 9, who are assigned or carry out missions outside of Chapter VII. For example, in humanitarian missions or in post-conflict areas, which are generally in vulnerable peace conditions (Peace Vulnerabilities), conflicts can surface quickly so that the possibility of deliberate attacks aimed at UN personnel and associated personnel may occur. The following lists are the number of personnel who died due to malicious acts such as attacks. ${ }^{23}$

Table 1.2

Number of UN personnel killed

\begin{tabular}{|l|c|c|}
\hline \multicolumn{1}{|c|}{ Misi } & Lokasi & TOTAL \\
\hline $\begin{array}{l}\text { United Nations Observer Mission in } \\
\text { Georgia (UNOMIG) }\end{array}$ & Georgia & 6 \\
\hline $\begin{array}{l}\text { United Nations Assistance Mission for } \\
\text { Rwanda (UNAMIR) }\end{array}$ & Rwanda & 14 \\
\hline $\begin{array}{l}\text { United Nations Truce Supervision } \\
\text { Organization (UNTSO) }\end{array}$ & Israel & 2 \\
\hline $\begin{array}{l}\text { United Nations Interim Force in } \\
\text { Lebanon (UNIFIL) }\end{array}$ & Lebanon & 22 \\
\hline
\end{tabular}

Based on the list, it is clear that UN personnel and associated personnel need to be protected under Article 7 of the Convention on UN personnel's safety. The host country bears protection for UN personnel and associated personnel as the operation's organizer. Article 7 is also often adopted into SOFA / SOMAs agreements between the host countries and the United Nations. Therefore, Article 7 becomes a basis for the parties to submit and provide the right to protect personnel's safety from crimes and deliberate attacks. The parties are obliged to cooperate with the United Nations.

\footnotetext{
${ }^{21}$ Article 9 point (1) \& (2) Convention on the Safety of United Nations and Associated Personnel. The intentional commission of: "a murder, kidnapping, or another attack upon the person or liberty of any United Nations or associated personnel; a violent attack upon the official premises, the private accommodation or the means of transportation of any United Nations or associated personnel likely to endanger his or her person or liberty..."

${ }^{22}$ Article 7 Convention on the Safety of United Nations and Associated Personnel. "United Nations and associated personnel, their equipment, and premises shall not be made the object of attack or any action that prevents them from discharging their mandate..."

${ }^{23}$ Jair van der Lijn \& Timo Smit, Op Cit.
} 


\section{Associated personnel and enforcement of jurisdiction against perpetrators of attack personnel.}

As explained, the protection of UN personnel and associated personnel are borne by the host country as the operation's organizer. Therefore, the host State must take the necessary measures in cases of crimes against UN personnel and associated UN personnel as provided for in Article 9. Thus, the Convention on UN personnel's safety stipulates that states parties are obliged to take appropriate measures. Necessary, namely to enforce jurisdiction over the perpetrators of attacking UN personnel. As regulated in Article $10 .{ }^{24}$ Article 10 above, which states or requires state parties, or instead requires the host country (Host Country) of a UN Mission to uphold its country's jurisdiction against attacks or other crimes deemed to have endangered personnel. The enforcement of jurisdiction can be determined by observing the elements, namely when the crime is committed on the State's territory or onboard a ship or aircraft registered in the State concerned. Second, the suspect is a citizen of the host country or a stateless person but residing in that country. If the State has determined its jurisdiction, the State must notify the SG of the United Nations. If later cancelling the jurisdiction, the State must also again notify the UN SG.

Therefore, based on the elucidation of Article 10, the appropriate territorial jurisdiction to apply in the case of the attack, by looking at the Lex locus delicti ${ }^{25}$ Whether the location where an attack occurs is the territory of the host country or not. If such action falls within the territory of the host country of a UN Mission, that country has the right to exercise jurisdiction over attacks that occur on its territory. Given that each country has sovereignty in its territory and is entitled to determine a national legal system that determines national law application based on jurisdiction. The steps needed by the host country against attacks that occur in its territory are detention, investigation, and extradition of the perpetrator to the court table by its National Law, considering that the crime is included in its territorial territory.

The State court has the most robust jurisdiction considering that it will be easier to find witnesses and evidence so that the trial process can be more effective and efficient. In the case of reparation, the International Court of Justice stated that if there was a violation of law or rights, the international organization could ask the responsible State to fulfil the agreed obligations in the common interest. The form of responsibility depends on the condition of the case, whether the country's laws are enforced or not. For example, On May 27 and July 26, 2011, there was an attack in which six troops from Italy and France were injured in the head. Result of Two roadside bomb attacks launched on United Nations Interim Force in Lebanon (UNIFIL) Mobile troops, in the Borj al-Shamali area, on the outskirts of Tire's port city. UNIFIL is a temporary force formed by the United Nations on March 19, 1978, based on UN Security Council Resolution No. 425 and No. $426 .^{26}$

Based on the attack that occurred at UNIFIL, it violated the regulations stipulated in the Convention on the Safety of UN Personnel, which are regulated in Article 9. In this attack, the attack was aimed at the UNIFIL troop's car, which was the official transportation for troops, and resulted in head injuries. In the case of the attack, Article 10 of the Convention on UN Personnel's Safety requires the host State to enforce its jurisdiction over the attack. Given that all sovereign independent States have jurisdiction over all people and objects within their territorial boundaries. So the Lebanese State as the host country has the right to enforce its

\footnotetext{
${ }^{24}$ Article 10 Convention on the Safety of United Nations and Associated Personnel "Establishment of jurisdiction..."

${ }^{25}$ Locus means "place," while dictum means "action against the law, crime, and criminal acts." So locus delicti means "the scene of the crime". Finally, adagio arises in the field of law with locus regit actum, which means "the place of the act determines the law applicable to the act" Available on S. Adiwinoto, Istilah Hukum (Jakarta: Intermasa, 1977), 34\&63.

${ }^{26} \mathrm{https}: / /$ unifil.unmissions.org/unifil-mandate accessed on June 12, 2020.
} 
jurisdiction, especially the attacks carried out, including the Lebanese territory, which occurred in the Borj al-Shamali area, on the port's outskirts city of Tire. Lebanon has the right to take steps in dealing with the attack case. However, in UNIFIL itself, Lebanon's country as the host did not address the attack's problem as stipulated in Article 13 and Article 14.

Based on Articles 13 and 14, which explain that if the circumstances allow, then the state parties in the territory suspected of being the perpetrator of the crime must take action by its National Law. The steps taken are to ensure the prosecution or extradition of the Convention's suspected violators without the slightest delay. Therefore, according to the elucidation of Articles 13 and 14, Lebanon must immediately take action by prosecuting the attackers by national law, bearing in mind that UN personnel and associated UN personnel must be appropriately protected. Suppose Lebanon cannot exercise its jurisdiction in enforcing the law against the perpetrators of the attack. In that case, the Lebanese State can seek assistance from the relevant countries, namely Italy and France, as stipulated in Article 16, which regulates Mutual Legal Assistance. Given that currently, in several cases, the State must prosecute and prosecute the attackers and the obligation to cooperate with other countries in arresting, detaining, and prosecuting and prosecuting perpetrators of international crimes or what is known as the au dedere au judicare principle. However, if the settlement cannot be completed, the state party can apply for assistance through UN organs. Given that international organizations' formation with international personalities results in new legal entities, separate from the countries' legal entities that form them.

Just as a state can be held responsible for violations of an organization's representatives' rights, can an organization be held responsible for such violations? International organizations can assist or assist countries in the law enforcement of an act. Therefore, the host country can apply for assistance through the UN Security Council. This is understandable because the UN Security Council has the primary responsibility of maintaining international peace and security. The UN Security Council can immediately conduct negotiations regarding this matter and provide recommendations on resolving the problem. The UN Security Council acts on behalf of UN member countries.

\section{Conclusion}

Personnel into two types and describes the scope of regulated operations to regulate personnel carrying out UN operational missions. The protection afforded is that their equipment and buildings must not be the object of attack or any action that prevents them from giving up their mandate. Article 9, which regulates prohibited actions, such as attacks, kidnappings, or killings deliberately aimed at personnel, until Article 10, which regulates state jurisdiction determination, where the State can determine its jurisdiction to protect personnel from extraditing the attackers. Against personnel. According to Article 10 of the Convention on the Safety of UN Personnel, the article requires the host State to enforce its jurisdiction over the attack based on the case of attacks on UNIFIL personnel.

So the Lebanon State, as the host country in the case of the attack, needs to uphold the country's jurisdiction. Therefore, the appropriate territorial jurisdiction to apply in the case of the attack is seen from the Lex locus delicti, which occurred in the Borj al-Shamali area, a suburb of Tire's port city, a part of Lebanon. Therefore the Lebanese State must establish its territorial jurisdiction, under which Lebanon is entitled to take the necessary steps. For example, detention, investigations, and extradition of the perpetrator to the court by the National Law, considering that the crime falls within its territory. However, in the case of UNIFIL itself, the Lebanese State as the host did not take action on the problem of the attack as stipulated in Articles 13 and 14, which State that the state party in its territory was the place where the violation occurred, the state party filed a prosecution or immediately extradited the perpetrator to the competent authorities without any exception and the slightest delay by the Law of the 
State concerned. Suppose Lebanon is unable to exercise its jurisdiction in enforcing the law against the perpetrators of the attack. In that case, the Lebanese State can seek assistance from the relevant countries, namely Italy and France, as stipulated in Article 16.

\section{REFERENCES}

\section{A. Journal}

Attina, Fulvio. "INTERNATIONAL RELATIONS AND CONTEMPORARY WORLD ISSUES", International Relations Encyclopedia of Life Support Systems (EOLSS) 2, 2005: 148-174, DOI: 10.4324/9780203984130-12.

Bayo, Ogunrotifa Ayodeji. "THE FACTORS BEHIND SUCCESSES AND FAILURES OF UNITED NATIONS PEACEKEEPING MISSIONS: A CASE OF THE DEMOCRATIC REPUBLIC OF CONGO”, Journal of Alternative Perspectives in the Social Sciences 3, no. 4, 2012: 914-932.

Burkle, Frederick M. "COMMENTARY UNITED NATIONS CHARTER, CHAPTER VII, ARTICLE 43: NOW OR NEVER", Disaster Medicine and Public Health Preparedness 13, no. 4, 2017: 655-66, DOI: 10.1017/dmp.2018.43.

Goulding, Marrack. "THE EVOLUTION OF UNITED NATIONS PEACEKEEPING", International Affairs 69, no. 3, 1993: 451-464, DOI: 10.2307/2622309.

Mpanza, Siphesihle E., Mlambo, Victor H. "UN PEACEKEEPING MISSIONS IN AFRICA, A CONUNDRUM OR OPPORTUNITY: A CASE OF THE DEMOCRATIC REPUBLIC OF CONGO, SOUTH SUDAN AND THE CENTRAL AFRICAN REPUBLIC", African Renaissance 16, no. 4, 2019: 9-32, DOI: 10.31920/2516-5305/2019/16n1a1.

Palchetti, Paolo. "INTERNATIONAL RESPONSIBILITY FOR CONDUCT OF UN PEACEKEEPING FORCES: THE QUESTION OF ATTRIBUTION", Sequência (Florianópolis) 70, 2015: 19-56, DOI: 10.5007/2177-7055.2015v36n70p19.

Rosyidin, Mohamad. "KONFLIK INTERNASIONAL ABAD KE-21? BENTURAN ANTAR NEGARA DEMOKRASI DAN MASA DEPAN POLITIK DUNIA", Jurnal Ilmu Sosial dan Ilmu Politik 18, no. 3, 2015: 223-236, DOI: 10.22146/jsp.13137

Samekto, Adji. "MENGKAJI PERAN OPERASI PEMELIHRAAN PERDAMAIAN PBB SEBAGAI BAGIAN UPAYA MENCIPTAKAN PERDAMAIAN DUNIA", Jurnal Hukum dan Pembangunan 21, no. 1, 1991: 25-35, DOI: 10.21143/jhp.vol21.no1.395.

Sarjoon, Athambawa., Yusoff, Mohammed Agus. "THE UNITED NATIONS PEACEKEEPING OPERATIONS AND CHALLENGES", Academic Journal of Interdisciplinary Studies 8, no. 3, 2019: 202-211, 202, DOI: 10.2478/ajis-2019-0059.

Stromseth, Jane E. "AN IMPERIAL SECURITY COUNCIL? IMPLEMENTING SECURITY COUNCIL RESOLUTIONS 1373 AND 1390", Georgetown Law Faculty Publications and Other Works 97, 2003: 41-54.

Weiß, Wolfgang. "SECURITY COUNCIL POWERS AND THE EXIGENCIES OF JUSTICE AFTER WAR", Max Planck Yearbook of United Nations Law 12, no. 1, 2008: 1-38, DOI: 10.1163/18757413-90000020a.

\section{B. Book}

Adiwinoto, S. Istilah Hukum. Jakarta: Intermasa, 1977.

Lijn, Jair van der., Smit, Timo. Peacekeepers Under Threat? Fatality Trends In UN Peace Operations. Stockholm: Stockholm International Peace Research Institute, 2015.

Shaw QC, Malcolm N. Hukum Internasional. Bandung: Nusa Media, 2013.

\section{Legislations}

Convention on the Safety 1994 
Report of the Ad Hoc Committee on the Scope of Legal Protection under the Convention on the Safety, UN GAOR 57th Sess., Supp. No. 52, UN Doc. A/57/52 (2002).

Report of the Ad Hoc Committee on the Scope of Legal Protection under the Convention on the Safety, UN GAOR 58th Sess., Supp. No. 52, UN Doc. A/58/52 (2003).

Report of the Ad Hoc Committee on the Scope of Legal Protection under the Convention on the Safety, UN GAOR 59th Sess., Supp. No. 52, UN Doc. A/59/52 (2004).

Resolution Adopted by the GA Forty-ninth session Agenda item 37 (c), A/RES/49/December 22131994.

Security Council Resolution 626, 1989.

Security Council Resolution 894 of 1994.

D. Internet

https://republika.co.id/berita/lja8rx/tni-bakal-terjunkan-tim-pertama-ke-haiti accessed on June $12,2020$.

https://unifil.unmissions.org/unifil-mandate accessed on June 12, 2020. 
